\title{
HAK MENGUASAI NEGARA, PERSPEKTIF INDONESIA SEBAGAI NEGARA HUKUM
}

\author{
Imam Koeswahyono ${ }^{1}$
}

\begin{abstract}
Abstrak
The right of management of the state since early Dutch colony until this recent transition era has became terminology that been debated. That controversy persists by the strength of the state intervention through the vital natural resources for agrarian nations beside biased articulation in discourse but also on state right in praxis terms. Those situations have prolonged even had begun any transformation in politic's paradigm of prior New Order (Orde baru) to the recent transition era and had not impacted to the reconceptualization through that state right and praxis. Under the author tought it needs significant effort which is based under legal pluralism, decentralization by the participative of legislative drafting method also sustainability and public anccountability principles. Without considering to those factors the author remark it would arise mis-perceptive through the right managament of the state, latent/massive conflict over regions that contra productive to development progress and such natural disasters.
\end{abstract}

Kata kunci: hak menguasai negara (HMN), negara hukum (rechtsstaat), hukum progresif

\section{Pendahuluan}

Masalah atau permasalahan tentang hak menguasai dari negara setidaknya telah menjadi wacana perbincangan setidaknya hampir tiga dasa warsa terakhir jika dihitung sejak diundangkanya Undang-undang No.5 Tahun 1960 tentang Ketentuan Dasar Pokok-pokok Agraria. Persisnya muncul sekitar tahun 1979 ketika masalah atau kasus pertanahan marak terjadi di berbagai wilayah di Indonesia sebagaimana fakta ini dikonstatasi oleh Maria SW. Soemardjono (1982). ${ }^{2}$ Walaupun akar persoalan pertanahan

${ }^{1}$ Penulis adalah Dosen tetap Fakultas Hukum Universitas Brawijaya Bidang Hukum Agraria, Alumnus S-2 Ilmu Hukum UGM, pernah sebagai sekretaris redaksi jurnal ilmu hukum "Arena Hukum" Fakultas Hukum Universitas Brawijaya tahun 1997 sampai 2005, sejak tahun 2007 menempuh pendidikan S-3 Ilmu Hukum di Universitas Brawijaya Malang. 
tidak hanya terletak pada hak menguasai negara semata, namun menurut beberapa hasil kajian lembaga swadaya masyarakat misalnya Konsorsium Pembaruan Agraria (KPA) Bandung terjadi bias antara ide (idea) dengan praktik seperti dinyatakan: "cita-cita ideal yang yang terkandung di dalam konsepsi HMN adalah menempatkan negara sebagai sentral yang mengatur mengatur kekayaan negeri untuk kemakmuran rakyat dengan prasyarat negara yang kuat dengan bentuk negara yang netral bebas dari kepentingan yang lain kecuali kepentingan mensejahterakan rakyat atau dalam bahasa Kuntowijoyo "negara budiman". Padahal kenyataannya, negara kemudian diboncengi oleh sejumlah kepentingan kelompok atau individu yang mengatasnamakan kepentingannya itu dengan kepentingan umum atau kepentingan rakyat atau kepentingan negara". Beberapa pembuktian secara empirik yang menyertai kajian-kajian lembaga swadaya masyarakat dari bebrbagai kasus di tanah air, semakin memberikan gambaran yang jelas bagaimana terjadinya penyimpangan antara ide HMN dengan praktik, sehingga mendorong gagasan untuk dilakukannya revisi atas Undang-undang No.5 Tahun 1960 yang substansinya antara lain memuat HMN yang dimaksud.

Konsep dasar hak menguasai tanah oleh negara (disingkat menjadi:HMN) termuat dalam Pasal 33 Ayat (3) UUD 1945 yang berbunyi: Bumi dan air dan kekayaan alam yang terkandung di dalamnya dikuasai oleh negara dan dipergunakan untuk sebesar-besar kemakmuran rakyat.

Menurut Pasal 2 UUPA, HMN hanya memberi wewenang kepada negara untuk mengatur:

a). mengatur dan menyelenggarakan peruntukan, penggunaan, persediaan, dan perneliharaan bumi, air dan ruang angkasa;

b). menentukan dan mengatur hubungan-hubungan hukum antara orang-orang dengan bumi, air dan ruang angkasa;

${ }^{2}$ Maria SW. Sumardjono, "Tinjauan Kasus Beberapa Masalah Tanah", Cetakan Pertama Edisi Revisi, (Yogyakarta: Jurusan Hukum Agraria Fakultas Hukum Universitas Gadjah Mada, 1982), hal. ix-x, memberikan gambaran terdapat empat kelompok masalah pertanahan yang mendorong pemerintah membentuk Tim Khusus Penanganan Kasus-kasus Tanah.

${ }^{3}$ Noer Fauzi dan Dianto Bachriadi, Hak Menguasai Dari Negara (HMN) Persoalan Sejarah Yang Harus Diselesaikan dalam Konsorsium Reformasi Hukum Nasional (KRHN) dan Konsorsium Pembaruan Agraria (KPA), Usulan Revisi UUPA Menuju Penegakan HakHak Rakyat Atas Sumber-sumber Agraria, Jakarta, 1998, hal. 213-214. 


\section{c). menentukan dan mengatur hubungan-hubungan hukum antara orang-orang dan perbuatan-perbuatan hukum yang mengenai bumi, air dan ruang angkasa.}

Peraturan perundang-undangan di bidang agraria, memberi kekuasaan yang besar kepada negara untuk menguasai semua tanah yang ada di wilayah Indonesia, sehingga berpotensi melanggar hak ulayat dan hak perorangan atas tanah. Oleh karena itu, di kalangan ahli hukum timbul gagasan untuk membatasi wewenang negara yang bersumber pada $\mathrm{HMN}$.

\section{Permasalahan}

Berpijak pada latar belakang permasalahan sebagaimana termaktub di muka, maka pada tulisan ini, dikemukakan permasalahan sebagai berikut:

1. Faktor-faktor apa yang menyebabkan terjadi penyimpangan konsep hak menguasai dari negara (HMN) di dalam peraturan perundangan agraria?

2. Bagaimana upaya yang seharusnya dilakukan oleh pemerintah ataupun pemangku kepentingan dari perspektif hukum untuk mengatasi permasalahan penyimpangan konsepsi hak menguasai dari negara (HMN) dalam konteks negara hukum?

\section{Pembahasan}

\section{A. Kajian Filosofi, Teoritik dan Praktik atas HMN}

Konsep yang oleh Soerjono Soekanto didefinisikan sebagai "kumpulan dari arti-arti yang berkaitan dengan istilah, biasanya dikaitkan dengan referensi yang bersifat empiris di dalam ilmu-ilmu sosial konsep sebaiknya diambil dari teori". Dalam perkembangan disiplin socio legal studies yang menurut pandangan Philipus Mandiri Hadjon (2006) dikatakan sebagai sociological jurisprudence dikaitkan dengan tema utama adalah kesenjangan (the gap) antara law in the books and law in action. Namun demikian studi tersebut hanya sampai pada tingkatan menggambarkan kesenjangan tetapi jarang menjelaskannya (the gap is described but rarely explained). ${ }^{4}$

${ }^{4}$ Philipus M Hadjon dan Tatiek Sri Djatmiati, "Argumentasi Hukum”, Cetakan Kedua, (Yogyakarta: UGM Press, 2005), hal. 4. 
Menurut Soemardjono (1998) pada konsep hak menguasai dari negara sesungguhnya terkandung kewenangan yang menurut Black (1991) bermakna "the lawful delegation of power by one person to another person which consists of the right and power of public officers to require obedience to their orders lawfully issued in the scope of their public duties". Wewenang yang didasarkan pada konsep hak menguasai dari negara itu difahami dalam kerangka hubungan antara Negara dengan bumi, air, kekayaan alam dan sebagainya dalam hubungan penguasaan dan bukan pemilikan sebagaimana konsep yang dianut oleh Amerika Serikat atau negara sosialis -komunis misalnya $\mathrm{RRC}^{5}$

Franz Magnis Suseno (1994) berpendapat sebagaimana disitir Sumardjono (1998) bahwa negara memperoleh kewenangan itu karena tidak semua permasalahan atau urusan dapat dilakukan atau diselesaikan oleh masyarakat sendiri. Fungsi Negara, di dalam penyelenggaraan sebagaian kepentingan masyarakat hanyalah bersifat melengkapi. Dalam hal-hal dimana masyarakat dapat menyelesaikan masalah dan kepentingannya sendiri dan selama hal tersebut tidak bertentangan dengan kepentingan atau hak pihak lain, maka campur tangan negara tidak diperlukan. ${ }^{6}$

Adapun asas yang melatar belakangi kewenangan negara adalah asas pendelegasian wewenang dari masyarakat kepada negara yang menurut Magnis bersifat universal. Dengan mengutip pemikiran John Locke, Magnis menyatakan negara (penguasa) menerima kekuasaan dari masyarakat dengan tujuan untuk melindungi kehidupan dan harta bendanya. Dengan demikian, negara wajib mempertanggungjawabkan penggunaan kekuasaannya. Hubungan antara masyarakat dan pemerintahnya adalah hubungan yang berdasarkan kepercayaan (trust) dan kewenangan negara dibatasi oleh tujuannya, yakni memberikan pelayanan kepada masyarakat. ${ }^{7}$ Simpulan yang dapat diambil dari uraian tersebut adalah hak menguasai negara diperoleh dari mandat rakyat kepada penguasanya berdasarkan prinsip kepercayaan dan menghendaki pertanggungjawaban atas pendelegasian kewenangan itu.

${ }^{5}$ Maria Sriwulani Sumardjono, Kewenangan Negara Untuk Mengatur Dalam Konsep Penguasaan Tanah Oleh Negara, Pidato Pengukuhan Guru Besar Hukum Agraria, Universitas Gadjah Mada, Yogyakarta, 14 Februari 1998, hal. 4.

${ }^{6}$ Ibid., hal. 6.

${ }^{7}$ Ibid. 
Sebagai salah satu Negara hkum moderen di kawasan Asia Tenggara, dengan jumlah penduduk serta luas wilayah terbesar, menurut beberapa pakar hukum tata Negara Indonesia, dapat dikategorisasikan sebagai Negara hukum moderen. Karakteristik yang membuktikan bahwa Negara Indonesia sebagai Negara hukum adalah:

1. Dijaminnnya hak-hak konstitusional rakyat dalam UUD

2. Dilakukannya pemilihan umum yang bebas, langsung dan rahasia untuk memilih wakil rakyat dan pemimpin negara dan daerah;

3. Sistem peradilan yang bebas dan adil

4. Perbaikan dan penataan supra dan infra struktur politik

Bernard Arief Sidharta (2000) dalam kajian disertasinya dengan mebagi kurun waktu atau periode pembangunan sistem hukum nasional, Indonesia cita hukum Pancasila yang sesungguhnya menjadi pedoman,norma kritik serta faktor memotivasi dalam penyelenggaraan, dan perilaku hukum harus terus didorong untuk dibangun untuk menggantikan cita dan sistem hukum kolonial yang sudah tidak relevan lagi dengan cita hukum dan kebutuhan hukum rakyat. $^{8}$

\section{B. Faktor-faktor Apa yang Menyebabkan Terjadi Penyimpangan Konsep Hak Menguasai Negara (HMN) di dalam Peraturan Perundangan Agraria}

Kajian lain yang menunjukkan faktor penyebab mengapa hak menguasai negara kemudian dalam praktik terjadi penyimpangan karena "dalam pelaksanaan pembangunan nasional yang diorientasikan untuk sekadar mengejar target/rate/kuantitas pertumbuhan ekonomi (economic growth development) dengan mengabaikan dimensi proses pada tiga dekade terakhir ini juga menimbulkan sengketa di daerah, sengketa antara pemerintah dan/atau pelaku usaha dengan komunitas masyarakat Adat karena dilaksanakan dengan menggunakan pendekatan keamanan dan represif (security and repressive approach) dengan memarjinalisasi nilai, norma hokum local, tradisi dan

8 Bernard Arief Sidharta, "Refleksi Tentang Struktur Ilmu Hukum, Sebuah Penelitian Tentang Fundasi Kefilsafatan dan Keilmuan Ilmu Hukum Sebagai Landasan Pengembangan Ilmu Hukum Nasional Indonesia", Disertasi, Cetakan Kedua, (Program Pascasarjana Univ. Padjadjaran, Bandung: CV Mandar Maju, 2000), hal. 180-185. 
kepercayaan masyarakat setempat". 9 Simpulan dari uraian di muka adalah kajian Nurjaya lebih mengedepankan pada perspektif bagaimana factor-faktor yang menyebakan terjadinya penyimpangan kewenangan negara berupa hak menguasai dari Negara sosialekonomi-antropologik, sehingga memberikan suatu gambaran bahwa adanya factor "interest atau kepentingan yang mengemuka dari pejabat Negara atau kelompoknya untuk menyimpang dari amanat rakyat. Fakta-fakta sosial-ekonomi yang melatarbelakangi atau mempengaruhi mengapa penyimpangan itu terjadi salah satunya karena ideologi neokapitalisme yang terjadi pada awal tahun 1970an setidaknya mempengaruhi dua produk peraturan perundang-undangan penting di bidang investasi yakni Undang-undang No.1 tahun 1967 tentang Penanaman Modal Asing (PMA) dan Undang-undang No.6 Tahun 1968 tentang Penanaman Modal Dalam Negeri (PMDN).

Berpijak dari pengaruh ideologi neo-kapitalisme sangat kuat pengaruh sampai kini terhadap produk peraturan perundangan yang dapat dibuktikan dari konsideran peraturan perundangan tersebut dengan istilah demi atau untuk kepentingan pembangunan, sehingga dalam banyak kasus membawa implikasi kepentingan rakyat harus "dikorbankan".

\section{Upaya yang Seharusnya Dilakukan oleh Pemerintah ataupun Pemangku Kepentingan dari Perspektif Hukum untuk Mengatasi Permasalahan Penyimpangan Konsepsi Hak Menguasai Negara (HMN)}

Dari penelitian yang dilakukan oleh penulis bersama dengan tim Pusat Pengembangan Hukum Agraria Fakultas Hukum Unibraw tahun 2003-2005 $5^{10}$ ditemukan: Pertama, pembatasan wewenang negara yang bersumber pada HMN yang diatur dalam UUPA, yaitu: a).Wewenang negara yang diatur dalam Pasal 2 Ayat (2) dibatasi oleh, isi dari hak atas tanah. Artinya, wewenang negara itu dibatasi oleh, wewenang yang dipunyai oleh pemegang hak atas tanah untuk menggunakan

${ }^{9}$ I Nyoman Nurjaya, Reorientasi Paradigma Pembangunan Hukum Negara Dalam Masyarakat Multikultural: Perspektif Antropologi Hukum, Pidato Pengukuhan Guru Besar Antropologi Hukum, Universitas Brawijaya, Malang, 10 September 2007, hal. 2.

${ }^{10}$ Pusat Pengembangan Hukum Agraria dan Pusat Penelitian dan Pengembangan Badan Pertanahan Nasional (Puslitbang BPN), Penelitian tentang Evaluasi Atas Undangundang Pokok Agraria, Hasil Penelitian, Tidak Dipublikasikan \& Diterbitkan Terbatas, Malang, 2003-2005, hal. $x$ dan 45-47. 
haknya; b).Wewenang negara yang diatur dalam Pasal 4 Ayat (1) dan Pasal 8 dibatasi oleh, pemberian hak atas tanah atau hak-hak lainnya dan pengambilan SDA tidak boleh melanggar hak perorangan atas tanah dan hak masyarakat hukum adat atas tanah ulayatnya. Kedua, implementasi wewenang negara yang bersumber pada HMN terhadap hak ulayat. Dalam pemberian hak atas tanah atau hak-hak lainnya dan pengambilan SDA, terjadi pelanggaran terhadap hak ulayat seperti pada kasus Pertambangan Freeport di Papua dan Pertambangan Emas Kelian di Kalimantan. Agar wewenang negara itu tidak melanggar hak Ulayat, maka dalam pemberian hak atas tanah atau hak-hak lainnya dan pengambilan SDA, tidak boleh menghilangkan hak-hak masyarakat hukum adat yang berdasar pada hak ulayatnya. Ketiga, implementasi wewenang negara yang bersumber pada HMN terhadap hak perorangan atas tanah. Dalam pengadaan tanah untuk pembangunan demi kepentingan umum, terjadi pelanggaran terhadap hak perorangan atas tanah seperti pada kasus Cimacan dan kasus Waduk Jatigede. Agar pelanggaran tersebut tidak terjadi, pengadaan tanah untuk pembangunan hanya dapat dilakukan apabila ada persetujuan dari pemegang hak atas tanah tanpa disertai dengan intimidasi dalam bentuk apapun. Keempat, ditemukan adanya peraturan perundang-undangan yang mengatur eksistensi hak ulayat bersifat mendua, artinya di satu sisi eksistensi hak ulayat diakui dan dilindungi, namun pada sisi lain juga diingkari. Dalam tataran konsep secara de jure hak ulayat diakui dan dilindungi oleh UUD 1945, Tap MPR dan UUPA, narnun pada tataran implementasi secara de facto hak ulayat diingkari oleh Undang-undang Nomor 41 Tahun 1999, Undang-undang Nomor 11 Tahun 1967 dan Undang-undang Nomor 22 Tahun 2002.

Esensi utama upaya untuk mengatasi masalah dalam dalam penelitian Muhammad Bakri adalah, pembatasan wewenang negara yang bersumber pada HMN. Dari sentral masalah tersebut dirinci 3 sub masalah, yaitu:

a). Pembatasan wewenang negara yang bersumber pada hak menguasai tanah oleh negara yang diatur dalam UUPA;

b). Implementasi wewenang negara yang bersumber pada $H M N$ terhadap hak ulayat;

c). Implementasi wewenang negara yang bersumber pada $H M N$ terhadap hak perorangan atas tanah. 
Muhammad Bakri (2007) penelitian hukum yang menggunakan pendekatan sejarah, peraturan perundang-undangan, konseptual dan pendekatan kasus untuk menemukan pembatas hak menguasai tanah oleh negara. Bahan hukum penelitian terdiri atas: bahan hukum primer yaitu, peraturan perundang-undangan dan jurisprudensi; dan bahan hukum sekunser adalah, bahan hukum yang diperoleh dari studi kepustakaan. Analisis bahan hukum menggunakan analisis isi. ${ }^{11}$

Dalam perkembangan bergulirnya pandangan mengenai ketidaksesuaian konsep hak menguasai dari negara atas sumber daya agraria khususnya yang sempat menguat pada tahun 1997/1998 sampai keluarnya Ketetapan Majelis Permusyawaratan Rakyat No.IX/MPR/ 2001 tentang Reforma Agraria dan Sumber Daya Alam justru mengalami anti klimaks menurun tensinya. Tentunya, harus dipertanyakan mengapa wacana perdebatan hak menguasai negara semakin mengendur dan ironisnya pemerintah sama sekali tidak mengambil keputusan untuk melaksanakan amanat ketetapan MPR tersebut.

\section{Upaya Reforma Agraria Mampukah Memberi Solusi HMN?}

Penulis, sengaja menggunakan istilah reforma (asal bahasa Spain/Spanyol/Espanola, sedang dalam bahasa Inggris Reform) bukan reformasi sebagaimana dipakai oleh Muhammad Bakri (2007) dengan pertimbangan bahwa reform merupakan suatu perubahan yang dilakukan secara mendasar/fundamental bukan gradual/bertahap yang "diawali dengan perubahan kebijakan (policy change) dan perubahan hukum (law reform) dengan asumsi bahwa hukum merupakan ekspresi dari rasa keadilan rakyat. ${ }^{9}$ Sebagai upaya melaksanakan, maka FAO, Russel King (1977), Yujiro Hayami (1990) sebagaimana dikutip Wiradi (2000) menetapkan empat syarat yang wajib dipenuhi yakni:

a. Kemauan politik (dalam arti yang sungguh-sungguh) dari elit penguasa harus ada;

b. Elit pemerintahan/birokrasi harus terpisah dari elit bisnis (inilah sulit menciptakannya);

c. Partisipasi aktif dari semua kelornpok sosial harus ada. Organisasi rakyat/tani yang pro-reform harus ada;

${ }^{11}$ Muhammad Bakri, "Hak Menguasai Tanah Oleh Negara (Paradigma Baru Untuk Reformasi Agraria)", Disertasi, Cetakan Pertama, (Yogyakarta: Citra Media, 2007), hal. x dan 127. 


\section{d. Data dasar masalah agraria yang lengkap dan teliti harus ada. ${ }^{12}$}

Nampaknya banyak persyaratan yang dalam konteks Indonesia, belum terpenuhi ambil contoh masalah data dasar agraria saja masih simpang siur antar institusi tidak sama, KPA Bandung berdasarkan data yang dimiliki jumlah kasus tanah di Indonesia 1970-2001 sekitar 1700, sernentara Badan Pertanahan Nasional sebagaimana dinyatakan Joyo Winoto (2007) dalam rapat kerja dengan Komisi II DPR 5 Juni 2007 jumlah kasus 2.810 kasus sengketa yang belum diselesaikan, 1.065 kasus menjadi perkara di pengadilan, 1.043 yang ditangani melalui mediasi, sementara 322 kasus meningkat menjadi konflik yang $36,85 \%$ bersubyek warga masyarakat. ${ }^{13}$

Belum lagi persoalan misalnya dengan point $b$ dimana elit birokrasi juga sebagai pengusaha yang melahirkan Undang-undang No.25 Tahun 2007 tentang Penanaman Modal Asing (PMA) dimana salah satu pasal menyatakan HGU diberikan langsung 95 tahun dengan argumentasi undang-undang tersebut untuk mengakomodasi kepentingan penanaman modal asing. Bagaimanapun desakan kapitalisme global yang semakin mencengkeram, sehingga sumber daya yang menguasai hajat hidup segenap bangsa yakni sumber daya tanah dikuasai pula melalui berbagai daya dan upaya. Ibarat pendulum, kini posisinya condong ke arah kepentingan pemodal/kapitalis.

Dengan demikian dalam konteks disertasi Muhammad Bakri (2007) unifikasi merupakan suatu konsep dimana adanya politik hukum untuk menyatukan keberagaman pengaturan di bidang hukum agraria yang dikenal dengan hukum Adat ke dalam penyatuan hukum untuk berbagai wilayah hukum. Politik hukum demikian di dasarkan pada pertimbangan untuk mengubah politik hukum pada masa sebelumnya (kolonialisme \& imperialisme) Belanda. Kedua, adanya pemikiran sederhana yakni pragmatisme dalam arti memperrnudah birokrasi pemerintah untuk mengatur persoalan agraria dl sesuaikan dengan tujuan pembentukan negara kesatuan Republik Indonesia (eenheidstaat). Istilah yang dikemukakan Bakri (2007) sama dengan istilah pada Ketetapan Majelis Permusyawaratan Rakyat

${ }^{12}$ Gunawan Wiradi, "Reforma Agraria, Perjalanan Yang Belum Berakhir", Cetakan Pertama, (Yogyakarta: Insist Press, KPA dan Pustaka Pelajar, 2000), hal. 76-83.

${ }^{13}$ Periksa Kertas Posisi Konsorsium Pembaruan Agraria (KPA), Bandung No. 2-4 Tahun 2001 tentang Data tersebut yang juga dipublikasikan di dalam websitenya <www.kpa.or.id>, dan Majalah Tempo 10 Desember 2006 wawancara dengan Kepala Badan Pertanahan Nasional, "Reforma Agraria Tak Boleh Sembrono", hal. 46-50. 
No.IX/MPR/2001 tentang Pembaruan Agraria dan Pengelolaan Sumber Daya Alam yakni pluralisme dalam kesatuan. ${ }^{14}$ Catatan kritis penulis, istilah ini harus ditafsirkan hati-hati karena seolah kontradiktif. Tanpa memahami teori pluralisme hukum secara benar, maka istilah ini akan menyesatkan (fallacy) tidak saja bagi pengambil kebijakan namun juga rakyat, dengan demikian dibutuhkan upaya reorientasi paradigma pembangunan hukum. ${ }^{15}$

Beranjak dari fakta di lapang, upaya untuk mereorientasi telah mulai dilakukan setidaknya posta diundangkannya Tap No.IX/MPR/2001 di berbagai daerah dengan model legal drafting yang berbasis dari bawah (bottom-up legal drafting model) dengan berbagai peluang dan tantangannya. Namun tantangan terbesar niat baik tersebut memperoleh intervensi yang paling kuat dari variabel politik dan ekonomi seperti dikatakan Pramudya (2007) diperlukan adanya suatu upaya menserasikan kepentingan-kepentingan kelompokkelompok kepentingan baik pada aras vertikal maupun horizontal dengan keharusan melihat nilai-nilai yang berasal dari keyakinan, aspirasi dan kebutuhan masyarakat. ${ }^{16}$

Kembali kepada persoalan HMN dikaitkan dengan isu terakhir mengenai sumber daya agraria yakni program reforma agraria plus yang dideklarasikan kembali oleh presiden tanggal 10 Januari $2007 .{ }^{17}$ Dengan skema model sebagai berikut:

${ }^{14}$ Periksa Pasal 4 huruf c TAP MPR No.IX/ MPR/ 2001 dengan rumusan kalimat "menghormati supremasi hukum dengan mengakomodasi keanekaragaman dalam unifikasi hukum". Penafsiran atas istilah keanekaragaman dalam unifikasi hukum diperlukan pemahaman atas teori pluralisme hukum yang kritis bahwa produk hukum sejak lahir sarat dengan kepentingan, senantiasa berubah (mengalir menurut istilah Satjipto Rahardjo (2007) ), sehingga atau sekadar sensitizing cocept menurut Rikardo Simarmata (2005) periksa kaitannya dengan catatan kaki 15 .

${ }^{15}$ I Nyoman Nurjaya, Op. Cit., hal. 14-23.

${ }^{16}$ Pramudya, "Hukum Itu Kepentingan", Cetakan Pertama, (Salatiga: Sanggar Mitra Sabda, 2007), hal. xix-xxi dan 105 - 110. Bandingkan dengan hasil penelitian media massa yang berkembang di kalangan legislatif bahwa setiap produk hukum yang terkait kepentingan hajat hidup strategik seperti hutan, tanah, minyak, telepon, listrik memiliki harga tinggi dalam proses pembahasan legislasi yang secara conditio sine qua non keberpihakan norma kaidah itu pada kepentingan sekelompok/beberapa kelompok saja. Sebaliknya mengakibatkan berkarakter menindas kelompok mayoritas misalnya kasus: Kehutanan, Perkebunan, Sumber Daya Air, Minyak dan Gas Bumi, Tata Niaga Perberasan, Tebu dan sebagainya. 


\section{Ragaan Model \& Mekanisme \\ Penetapan Subyek \& Obyek \\ Program Pembaruan Agraria Nasional BPN 2007}

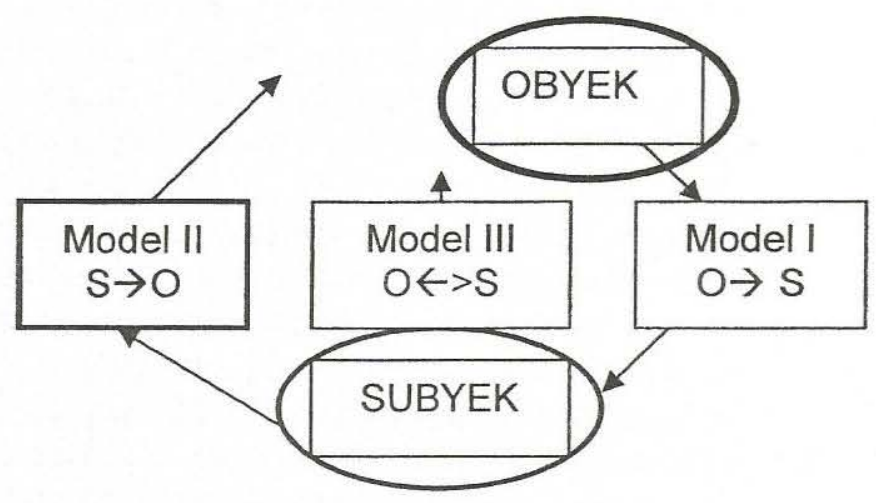

Keterangan: S adalah Subyek/pemegang hak; $\mathrm{O}$ adalah obyek yakni sumber daya tanah

Sumber: Badan Pertanahan Nasional (BPN) Maret $2007^{18}$

harus diaktualisasikan ke dalam program kongkrit untuk melakukan revisi atas seluruh peraturan perundangan agraria serta menugasi Badan Pertanahan Nasional bersama pemangku kepentingan lainnya untuk melakukan sinergi mewujudkan agenda reforma agraria.

Berkaitan dengan ide reforma agraria, maka persoalan mendasar yang harus difahami dengan baik adalah faktor hukum memegang arti yang terpenting sebagaimana dikatakan Tamanaha (2001) law is a mirror of society, which functions to maintain social order sebagai komponen utama, komponen kedua keterkaitan antara tiga unsur:

${ }^{17}$ Merupakan program yang sesungguhnya senafas dengan Ketetapan MPR No.IX/ MPR/2001 yang tidak dilaksanakan oleh ekskutif pada eranya menyusul diundangkannya Undang-undang No.10 Tahun 2004 khususnya Pasal 7 Ayat (1), (2) dan Ayat (4) merupakan suatu asa baru bagi yustisiabel terutama yang bersangkut-paut dengan hak-hak atas sumber daya agrarianya telah terampas.

${ }^{18}$ Relasi subyek baik orang maupun badan hukum dengan sumber daya tanah dari ragaan di atas lebih dalam tataran arm chair theory, mengapa karena bukti menunjukkan bahwa data yang dipakai untuk menentukan obyek tanah yang hendak diredistribusikan acapkali berbeda antara lembaga yang satu dengan lembaga yang lain misalnya: Departemen Kehutanan dengan Badan Pertanahan Nasional, Badan Koordinasi Survai Pemetaan Nasional, Departemen Pertambangan dan Biro Pusat Statistik (BPS) disamping lemahnya koordinasi antar lembaga terkait. 
custom/ consent, morality/reason, dan positive law. ${ }^{19}$ Terkait dengan pandangan Tamanaha, maka norma hukum positif refers to rules articulated and enforced by an institutionalized authority secara realita terjadi interaksi dengan dua unsur lainnya: custom dan morality dengan karakteristiknya yang imperatif/will. ${ }^{20}$ Paralel dengan pendapat Tamanaha tersebut, maka norma hukum positif mengenai hak menguasai negara pada Pasal 2 Undang-undang No.5 Tahun 1960 sesungguhnya tidak boleh bertentangan dengan Pasal 3 undangundang yang sama yang intinya "hak Ulayat diakui sepanjang kenyataannya masih ada, harus sedemikian rupa sehingga sesuai dengan kepentingan nasional dan Negara yang berdasarkan atas persatuan bangsa serta tidak boleh bertentangan dengan undangundang dan peraturan-peraturan lain yang lebih tinggi" justru norma ini bertentangan dengan realitas unsur custom/consent dan morality sebagaimana dimaksud Tamanaha seperti ditegaskannya " they are thought reflect one another, to feed or influence one another, and to determine the efficacy of one another. The relations between custom, morality and Positive law are parallel in many respect, especially with regard to the issue of legitimation". ${ }^{21}$ Kesimpulan yang dapat ditarik dari pandangan Tamanaha, adalah pendekatan positifistik tidak akan mampu menjawab persoalan mendasar, mengapa sejak sekitar 1979 telah terjadi resistensi masyarakat Adat yang merasa hak-haknya terampas oleh negara yang mendasarkan pada norma hak menguasai negara? Norma hak menguasai negara tidak dapat dilepaskan dari setting sosial dimana norma itu diberlakukan karena akan terjadi perjumpaan (meeting of two or more realities), saling mempengaruhi bahkan bisa jadi saling menegasikan.

Dengan demikian relasi antar tiga unsur esensial seperti dinyatakan Tamanaha agar seperangkat kaidah atau norma dapat efektif dilaksanakan, maka upaya yang antara lain dapat dilakukan melalui penafsiran/interpretasi atas konsep hak menguasai negara salah satu jalan adalah melalui jalan atau secara hermeneutik. ${ }^{22}$

${ }^{19}$ Brian Z Tamanaha., "A General Jurisprudence of Law And Society", First Edition, (USA: Oxford University Press, 2001), p. 1.

${ }^{20}$ Ibid. hal. 4-5.

${ }^{21}$ Ibid. hal. 9. 
Mengapa hal ini ditawarkan penulis, karena melalui metode hermeneutik ini akan terjadi proses menggali dan meneliti maknamakna hukum dari perspektif para pengguna atau pencari keadilan secara terus menerus. Dengan demikian arti suatu konsep tidak selamanya stagnan, statis melainkan dinamis seiring dengan perkembangan masyarakat atau komunitas yang bersangkutan. Atas dasar berfikir demikian, maka seharusnya model reforma agraria versi Badan Pertanahan Nasional harus didialogkan atau disepakatkan dengan semua pemangku kepentingan. Bukan malah sebaliknya atas dasar sebagai otoritas lembaga negara formal secara sepihak menyatakan model itu harus dilaksanakan dan dipatuhi masyarakat.

\section{Penutup}

Sebagai kesimpulan akhir tulisan ini, penulis hendak menegaskan kembali bahwa hak menguasai negara (HMN) harus dilakukan rekonseptualisasi agar tidak terjadi kembali penyalahgunaan kewenangan oleh pemerintah atas nama negara dengan mempersempit tafsir/ interpretasi menjadi mengatur dengan sangat rigid sehingga menegasikan partisipasi apalagi mengartikulasikan dengan memiliki.

Revisi atas Undang-undang No.5 Tahun 1960 beserta peraturan perundangan yang terkait dengan agraria seperti: UU No.19 Tahun 2004, UU No.18 Tahun 2004, UU No.7 Tahun 2004, UU No.11 Tahun 1967 maupun Undang-undang No.32 Tahun 2004, Undang-undang No.25 Tahun 2007, Undang-undang No.26 Tahun 2007 merupakan suatu keniscayaan, karena terjadi konflik norma (conflict of norms) maupun konflik nilai (conlict of values). Desakan ideologi kapitalisme, harus disikapi dengan tindakan kongkrit oleh pemerintah (atas nama negara) hendak dikemanakan Undangundang No.5 Tahun 1960: diubah sebagian: besar/kecil, atau hendak diganti total dengan kejelasan politik hukumnya.

${ }^{22}$ Hermeneutics atau hermeneia (Yunani) diartikan sebagai penafsiran/interpretasi, sehingga merupakan sebuah proses transformasi pemikiran dari yang kurang jelas atau ambigu menuju yang lebih jelas/konkrit periksa Jazim Hamidi, Hermeneutika Hukum, Cetakan Pertama, (Yogyakarta: Universitas Islam Indonesia Press, 2005), hal. 19-20, bandingkan dengan "suatu paradigma interpretatif mencoba membebaskan kajian-kajian hukum dari otorianisme para yuris positif yang elitis dengan strategi metodologisnya mengajak para pengkaji hukum agar menggali dan meneliti makna-makna hukum dari perspektif para pengguna atau pencari keadilan" menurut Otje Salman dan Anton F Susanto, Teori Hukum, Mengingat, Mengumpulkan dan Membuka Kembali, Cetakan Pertama, (Bandung: PT. Refika Aditama, 2004), hal. 81 - 82. 
Pertarungan semakin sengit di era globalisasi, menurut pandangan penulis membawa pada implikasi negara Indonesia khususnya pemerintah harus segera membuat langkah konkrit untuk membuat penataan secara menyeluruh sistem hukum nasional dan kelembagaannya sebagai skala prioritas. Jika tidak, maka secara logis konsekuensinya walaupun negara Indonesia memiliki potensi yang besar baik SDM maupun sumber daya alam, namun bila tidak membangun sistem hukum yang kuat dipastikan akan terus terjajah oleh rezim neo-kapitalistik yang kejam. 


\section{Daftar Pustaka}

Akbar, Andri, dkk (Penterjemah). Pluralisme Hukum, Sebuah Pendekatan Interdisiplin, Cetakan Pertama, Jakarta: HuMa dan Ford Foundation, 2005.

Bakri, Muhammad. Hak Menguasai Tanah Oleh Negara (Paradigma Baru Untuk Reformasi Agraria), Disertasi, Cetakan Pertama, Yogyakarta: Citra Media, 2007.

Fauzi, Noer dan Dianto Bachriadi. Hak Menguasai Dari Negara (HMN) Persoalan Sejarah Yang Harus Diselesaikan dalam Konsorsium Reformasi Hukum Nasional (KRHN) dan Konsorsium Pembaruan Agraria (KPA),Usulan Revisi UUPA Menuju Penegakan Hak-Hak Rakyat Atas Sumber-sumber Agraria, Jakarta, 1998.

Hamidi, Jazim. Hermeneutika Hukum, Cetakan Pertama, Yogyakarta: Universitas Islam Indonesia Press, 2005.

Kertas Posisi Konsorsium Pembaruan Agraria (KPA) Bandung No. 2-4 Tahun 2001 tentang Data tersebut yang juga dipublikasikan di dalam websitenya, <www.kpa.or.id>.

Koeswahyono, Imam, dan Tunggul Anshari Setianegara. Bunga Rampai Politik dan Hukum Agraria di Indonesia, Cetakan Kedua Edisi revisi, Malang: UM Press, 2000.

M. Hadjon, Philipus dan Tatiek Sri Djatmiati. Argumentasi Hukum, Cetakan Kedua, Yogyakarta: UGM Press, 2005.

Majalah Tempo 10 Desember 2006 wawancara dengan Kepala Badan Pertanahan Nasional, Reforma Agraria Tak Boleh Sembrono.

Nurjaya, I Nyoman. Reorientasi Paradigma Pembangunan Hukum Negara Dalam Masyarakat Multikultural: Perspektif Antropologi Hukum, Pidato Pengukuhan Guru Besar Antropologi Hukum, Universitas Brawijaya, 10 September, Malang, 2007.

Pramudya. Hukum Itu Kepentingan, Cetakan Pertama, Salatiga: Sanggar Mitra Sabda, 2007.

Pusat Pengembangan Hukum Agraria Fakultas Hukum Unibraw dan Pusat Penelitian dan Pengembangan Badan Pertanahan Nasional, 2003-2005 Penelitian tentang Perubahan Atas Undang-undang No. 5 Tahun 1960, Laporan Hasil Penelitian, Tidak Diterbitkan, Malang. 
Salman, Otje dan Anton F Susanto. Teori Hukum, Mengingat, Mengumpulkan dan Membuka Kembali, Cetakan Pertama, Bandung: PT. Refika Aditama, 2004.

Sidharta, Bernard Arief. Refleksi Tentang Struktur Ilmu Hukum, Sebuah Penelitian Tentang Fundasi Kefilsafatan dan Keilmuan Ilmu Hukum Sebagai Landasan Pengembangan Ilmu Hukum Nasional Indonesia, Disertasi, Cetakan Kedua, Program Pascasarjana Univ.Padjadjaran, Bandung: CV Mandar Maju, 2000.

Soemardjono, Maria SW. Kewenangan Negara Untuk Mengatur Dalam Konsep Penguasaan Tanah Oleh Negara, Pidato Pengukuhan Guru Besar Hukum Agraria, Universitas Gadjah Mada, Yogyakarta,14 Februari 1998.

Tinjauan Kasus Beberapa Masalah Tanah, Cetakan Pertama Edisi Revisi, Jurusan Hukum Agraria Fakultas Hukum Yogyakarta: Universitas Gadjah Mada, 1982.

Tamanaha, Brian Z. A General Jurisprudence of Law And Society, First Edition, USA: Oxford University Press, 2001.

Wiradi, Gunawan. Reforma Agraria, Perjalanan Yang Belum Berakhir, Cetakan Pertama, Yogyakarta: Insist Press, KPA dan Pustaka Pelajar, 2000 . 